\title{
Federalism under Putin
}

In August 1991 Yeltsin created two new administrative bodies to keep the regions in check: presidential representatives and regional governors. Between 1991 and 1996 Yeltsin was able to maintain control over the governors through his powers of appointment. However, once Yeltsin relinquished these powers and governors were able to come to power via the ballot box (see chapter 6), he was forced to turn to his presidential representatives to win back control of the regions.

As we noted in chapter 3 one of the major powers of the governors was their control over the appointment of the heads of federal bodies situated in their territories. By controlling the appointment of such powerful officials (e.g., heads of the tax inspectorate, financial oversight bodies, and customs officers, the judiciary, procuracy, central electoral commissions and others), regional executives were able to undermine the authority of the federal government and to thwart the implementation of federal policies. In some regions (for example Stavropol') governors were even able to appoint their own regional security councils thus giving them a significant degree of leverage over the 'power ministries' (security, internal affairs) in their territories.

According to Yeltsin's Presidential Decree of August 24, 1991, 'On Representatives of the President of the RSFSR in Krais and Oblasts of the RSFSR', the presidential representatives were charged with overseeing the work of the governors and federal agencies. However, three further presidential decrees followed in a largely unsuccessful attempt to raise the profile of the representatives. ${ }^{1}$ In the last of these decrees promulgated in July 1997 the presidential representatives were given increased powers to monitor the implementation of federal programmes and to coordinate the activities of the myriad of federal bureaucracies situated in the regions.

However, these decrees failed to give the representatives sufficient powers and resources to challenge the authority of the popularly elected governors. Many of the envoys appointed by Yeltsin had strong ties with their regions, and they soon turned 'native' taking on the interests of those 
whom they were supposed to be controlling. Moreover, governors in many regions captured control over the appointment of the representatives. In some cases bilateral treaties actually gave the governors the right to appoint their own presidential representatives or to approve presidential nominees. Indeed, in some cases presidential representatives were actually high ranking members of regional elites. Thus, for example, in Stavropol' Krai we had the absurd sitation whereby the presidential representative simultaneously held the post of deputy governor of the region. In 1994 Yeltsin bowed to the will of the Primorskii krai regional administration and sacked his presidential representative. ${ }^{2}$

Other more loyal lieutenants of the President simply did not have sufficient authority, or the resources, to stand up to the governors. The representatives relied on the regional administrations to supply them with housing, office space, transportation and other administrative supports. The governors also controlled access to the best schools and hospitals, and other local services for the families of the envoys. As Hyde notes, by the mid-1990s, 'Some representatives came to fulfill a function better described as representative of the regions to the centre'. ${ }^{3}$ Indeed, in 1997 the situation was so bad that the Kremlin was forced to replace 60 per cent of its representatives because of fears that 'their loyalty had been co-opted by the regional power elites' ${ }^{4}$ We should also note that the legislation setting up the presidential representatives was aimed at the regions and not the ethnic republics, many of which were able to escape the imposition of Yeltsin's envoys.

\section{Putin's radical assault on federalism}

It was Putin's election victories in 1999 and 2000 which paved the way for his audacious assault on the powers of the regional governors and his radical reform of the federal system. Armed with a democratic mandate from his impressive victory in the 2000 presidential elections, coupled with the surprise success of his presidential party Yedinstvo (Unity) in the December 1999 Duma elections, Putin was able to persuade a now 'tame parliament' that a radical overhaul of the federal system was essential if Russia was not to collapse into anarchy and ethnic turmoil. Moreover, Putin was able to win over key oligarchs to his view that the only way to bolster Russia's flagging economy was to reduce the anarchic powers of the governors, and to strengthen, 'the power-vertical'. As Putin stated in his message to the Federal Assembly: 'It's a scandalous thing when a fifth of the legal acts adopted in the regions contradict the country's Basic Law, when republic constitutions and province charters are at odds with the Russian Constitution, and when trade barriers, or even worse, border demarcation posts are set up between Russia's territories and provinces' ${ }^{5}$ In order, to 'restore an effective vertical chain of authority' and to imple- 
ment a uniform policy, Putin called for a 'dictatorship of law', in order to ensure that every citizen whether in Moscow or 'the most remote backwoods of Russia', would be guaranteed the same rights, and federal legislation would be 'understood and enforced' in a uniform manner throughout the federation. ${ }^{6}$

Putin's primary objectives are to create a unified economic, legal and security space in the federation and to tighten the federal government's controls over the regions. There are six major strands to Putin's federal reforms: (1) The creation of seven new federal super-districts, (2) a reform of the Federation Council, (3) the creation of a new State Council, (4) the granting of new powers to the President to dismiss regional governors and dissolve regional assemblies, (5) new rights for regional governors to dismiss municipal officials, and (6) a major campaign to bring regional charters and republican constitutions into line with the Russian Constitution. Below we examine each one of these reforms in turn.

By stressing the need to strengthen what he called the 'power vertical', Putin's reform agenda was very much in tune with many of the ideas which had recently been put forward by political parties in the run up to the 1999 Duma elections. Indeed, many of the same issues had already been raised by former Prime Minister Yevegenii Primakov. On coming to power in the autumn of 1998 Primakov had warned the country that the federation was in danger of splitting up into separate parts. And in January 1999 he called for a 'restoration of the vertical state power structure', demanding that separatist trends 'must be quelled, liquidated, and uprooted'. ${ }^{7}$ Primakov also sought to bring the governors under federal control by coopting them into the cabinet and government presidium. ${ }^{8}$ Thus for example, eight of the most powerful governors, each heading a regional economic association, were made members of the Presidium. ${ }^{9}$ After the anarchy of the Yeltsin years when the regions had almost turned into the 'personal fiefdoms' of the governors there was a general consensus that something had to be done to reinstate a single legal space in Russia.

\section{The creation of federal districts}

If Putin's major aim was to reassert federal authority over the regions then something had to be done to improve the work of the presidential representatives and to remove them from the clutches of the regional governors. And, even more importantly Putin had to recapture control over the work of the myriad of federal agencies which were situated in the regions and which had also fallen under the sway of the regional executives. Thus, on the May 13, 2000 Putin adopted what was to be the first of a package of decrees whose key aim was to rein in the power of the governors and to 'strengthen the unity of the state'. ${ }^{10}$ 
In this first major reform of the federal system, Putin divided the country into seven super-districts, each of which contained a dozen or more federal subjects, and he appointed a plenipotentiary representative (Polpredy 'Polnomochnyi Predstavitel' Prezidenta') to each district (see box 8.1). Putin deftly sidestepped calls to format the new districts to conform to the contours of Russia's eight inter-regional associations or eleven socioeconomic regions. Instead, the new federal districts were drawn up to closely match Russia's military districts, thus giving the envoys (most of whom had a background in the military or security organs, direct access to the command and control networks of the military garrisons in their districts. And in a blow against the sovereignty claims of the ethnic republics, Putin drew up the boundaries of the new federal districts in such a way that each district would include a mixture of ethnic republics and territorially defined regions. None of the capital cities of the federal districts are situated in an ethnic republic. This has led some commentators to speculate that the creation of the federal districs is but the first step in Putin's programme of levelling down the status of the republics to that of the regions. For a list of the districts and 'polpredy' see box 8.1.

However, many of the regions are not too happy with their new federal districts. Thus, for example, Astrakhan and Volgograd currently part of the Southern district would rather be in the Volga federal district. Perm, which is placed in the Volga district would rather be in the Urals, while Tyumen which is in the Urals wants to be part of the Siberian district, and Bashkortostan would like to be moved from the Volga District to the Urals. $^{11}$

Putin's creation of the seven federal districts and the instigation of the 'polpredy' fully comply with article 83 of the Russian Constitution which simply states that the President, 'appoints and removes plenipotentiary representatives of the President of the Russian Federation'. As Oracheva notes, 'the Constitution does not specify in what particular form this institution exists, what functions presidential representatives perform, how many representatives may be appointed' ${ }^{12}$ Thus, Putin can argue that the changes brought about by the May 13 decree were simply changes to his presidential administration, and not constitutional changes to the federation itself which would have been required to go through (and certainly failed to pass) complex and protracted amendement procedures provided for by the Constitution. However, as discussed below, Putin's federal reforms taken together undoubtedly are an assault on the federal idea and they certainly violate the spirit of the Constitution if not the actual Constitution itself.

\section{The administrations of the federal districts}

Five of the seven polpredy have a background in the army or security services. Of the two civilians, only one (Kirienko the former Prime Minister) 
Box 8.1 The seven federal districts

\section{Central District}

Presidential Representative: Lieutenant-General Georgii Poltavchenko.

District capital: Moscow. Belgorod, Bryansk, Ivanovo, Kaluga, Kostroma, Kursk, Lipetsk, Moscow, Orel, Ryazan, Smolensk, Tambov, Tver, Tula, Vladimir, Voronezh and Yaroslavl oblasts; and the city of Moscow.

\section{Far Eastern District}

Presidential Representative: Lieutenant General Konstantin Pulikovskii (retired). District capital: Khabarovsk. Republic of Sakha; Khabarovsk and Primorsky Krais; Amur, Kamchatka, Magadan and Sakhalin oblasts; the Jewish autonomous oblast; and the Koryak and Chukchi autonomous okrugs.

North-western District

Presidential Representative: Goneral Viktor Cherkesov.

District capital: St Petersburg.

Republics of Karelia and Komi; Arkhangelsk, Kaliningrad, Leningrad, Murmansk, Novgorod, Pskov and Vologda oblasts; the Nenets autonomous okrug; and the city of St Petersburg.

\section{Siberian District}

Presidential Representative: Leonid Drachevskii (April 5, 1942).

District capital: Novosibirsk.

Republics of Altai, Buryatia, Khakassia and Tyva; Altai and Krasnoyarsk Krais; Chita, Irkutsk, Kemerovo, Novosibirsk, Omsk and Tomsk oblasts; and the Evenk, Taimyr and Ust-Orda Buryat autonomous okrugs.

\section{Southern District}

Presidential Representative: Army General Viktor Kazantsev.

District capital: Rostov-on-Don.

Republics of Adygeya, Chechnya, Dagestan, Ingushetia, Kabardino-Balkaria, Kalmykia, Karachaevo-Cherkessia and North Ossetia; Krasnodar and Stavropol Krais; and Astrakhan, Rostov and Volgograd oblasts.

\section{Urals District}

Presidential Representative: Colonel-General (Police) Peter Latyshev.

District capital: Yekaterinburg.

Chelyabinsk, Kurgan, Sverdlovsk and Tyumen oblasts; and the Khanty-Mansii and Yamal-Nenets autonomous okrugs.

\section{Volga District}

Presidential Representative: Sergei Kirienko.

District capital: Nizhnii Novgorod.

Republics of Bashkortostan, Chuvashia, Marii El, Mordovia, Tatarstan and Udmurtiya; Kirov, Nizhnii Novgorod, Orenburg, Penza, Perm, Samara, Saratov and Ulyanovsk oblasts; and the Komi-Permyak autonomous okrug.

Source: RFE/RL Russian Federation Report, nos 18 and 19, 2000, compiled by Julie Corwin. 
has experience of working in politics at the national level, and the other is a former diplomat. In terms of responsibilities, their rank is somewhere between deputy chief of staff of the presidential administration and Deputy Prime Minister. ${ }^{13}$ The high status of the polpredy is also reflected in their membership of the Russian Security Council, and their right to attend cabinet meetings of the federal government. In fact, the decree setting up the federal districts was drafted by the Security Council. The status of the polpredy is also reflected in their regular meetings with the President. To prevent the polpredy going native the presidential administration will fund them directly.

The polpredy also have a not inconsiderable backup bureaucracy to assist them in their duties. In each of the seven federal districts there are approximately 100 members of staff. In addition, in each district there are also five 'deputy polpredy', a chief federal inspector, and a federal inspector appointed to each region within the federal districts.

Many of the major ministries have begun to restructure their administrations bringing them into line with the new federal districts. Thus, each of the federal districts now has a deputy prosecutor general and each district has a department for combating organised crime under the dual subordination of the polpredy and the Russian Minister of Internal Affairs. In addition, the Ministry of Justice also recently created branches in each of the seven districts and the Ministry of Finance, and the Tax Inspectorate have likewise begun to restructure their administrations in line with the reforms. Other federal bodies such as the Ministry of Health are in the process of following suit.

\section{Power and responsibilities of the polpredy}

The powers and responsibilities of the polpredy, at least on paper, are very impressive. Their key tasks are: (1) to monitor the regions' compliance with the Russian Constitution, federal laws and presidential decrees, (2) to oversee the selection and placement of personnel in the regional branches of the federal bureaucracy, (3) to protect the national security interests of the regions, and (4) to set up and coordinate within their districts inter-regional economic programmes. ${ }^{14}$ They also have the power to recommend to the President that he suspend specific local laws or decrees when they contradict federal laws and to call for the dismissal of governors and the dissolution of regional assemblies if they adopt decrees or laws which violate federal laws (see below).

Putin has been at pains to stress that the primary role of the polpredy are not to supplant the role of the elected governors but rather to coordinate the work of the federal agencies in the their districts. Putin noted: 'The authorised representatives, needless to say, will help in effectively solving the problems in their regions. But they do not have the 
right to interfere in areas under the jurisdiction of the electoral heads of the regions ${ }^{\prime} .^{15}$ This statement reminds one of pronouncements made during the Soviet era about the proper role of the party and state bodies. The party was charged with 'leading and guiding' the work of state bodies, but not 'supplanting' them. Of course, what happened in practice was quite the opposite, party bodies did meddle in the affairs of state bodies, often hindering, rather than helping them to carry out their administrative functions. It would appear that the polpredy may face a similar dilemma in their relations with the governors and federal bureaucracies.

One of the most important and controversial powers of the polpredy is that of the selection and placement of personnel. As presidential representative to the Volga district, Kirienko notes: 'In essence, the presidential representatives will oversee personnel policy for the president and will approve all appointments and promotions. The representatives will also maintain a reserve of personnel for all federal agencies' ${ }^{16}$ These powers will bring the polpredy into direct conflict with the governors who can cite article 72 of the Russian constitution to defend their right to be consulted over such appointments especially with regard to the judiciary and law enforcement bodies.

There is also some confusion over what controls the polpredy will be given in the economic sphere. Whilst they will not have direct control over the purse strings they are nonetheless charged with monitoring all the federal funds which come into their districts and overseeing the collection and transfer of taxes to the federal budget. Kirienko has stated that the districts will not have their own budgets. However, he did confirm that they will have their own socio-economic development plans, and thus, the ability to exercise some influence over economic policy making in the regions.

Thus, Putin's unelected polpredy have ostensibly been granted considerable powers over the internal politics of federal subjects and their democratically elected representatives. And it is difficult to imagine how these new federal representatives will be able to carry out their functions without infringing the constitutionally guaranteed rights of the federal subjects.

\section{The creation of seven quasi-states}

Whilst the powers of the polpredy seem impressive, it remains to be seen how effective they will be in practice. Given the fact that each presidential envoy will have to take charge of a dozen or so regions (whose administrative centres may be hundreds of miles apart), and the fact that every region has between forty and fifty federal agencies operating on its territory, this means that each presidential envoy will have to coordinate and 
control the work of approximately 400-600 agencies. In some of the very large districts it is difficult to see how the envoys will be able to exercise control over such vast territories and/or populations. Moreover, as we noted in chapter 5 the formation of the new federal districts has made the Federation even more asymmetrical. Thus, for example, almost half of the Russian population is situated in just two of the federal districts: the Central district and the Volga district.

Putin's reforms may simply have created seven powerful quasiregional states. Already the polpredy have begun to create the institutions necessary to turn their districts into mini-regional states. Thus, for example, we are beginning to see the development in the federal districts of councils of the heads of regional legislative and executive bodies (minifederal councils), councils of regional governors (mini-state councils). Councils for local self-government, and expert consultative and scientific research councils. ${ }^{17}$ Thus, for example Poltavchenko has created a council in his federal district which includes all the chief executives of the eighteen regions under his jurisdiction. ${ }^{18}$ The council will deal with all aspects of economic development. The new council would also appear to usurp the role of the Black Earth and Central Russian inter-regional economic associations.

In the Volga district, Kirienko has created a coordinating council for regional legislative chairmen. The aim of the council is to develop a united approach for drafting regional legislation and bringing regional laws into line with federal norms. These new mini-councils will soon co-exist next to a series of new district-level banks and financial bodies. ${ }^{19}$

Emboldened by their new powers to appoint leaders of the regional branches of the All Union Television and Radio Company the polpredy have also been actively promoting the development of a 'single information space' in each of their federal districts. To this end they have also set up district-wide mass media councils. Now the press will not only come under the control of the governors but the polpredy, hardly a recipe for the creation of a vibrant and open 'civil society' in Russia.

The capital cities of the seven federal districts are also rapidly becoming the home to new branches of the federal bureaucracy. Thus, for example, in addition to the district offices of the law-enforcement and justice departments, the following agencies have been established in Rostov region: the inter-regional Tax Inspectorate, the Federal Tax Police Service's Chief Administration for the Southern Federal District, the Southern Customs Administration, the Southern District Inspectorate of the President's Oversight Administration; the Russian Finance Ministry's Oversight and Auditing Administration for the Southern Federal District, the District Administration of the Federal Service for Financial and Bankruptcy, and others. There are twenty-eight district government agencies in all. ${ }^{20}$ These developments have further undermined the 
constitutional equality of the federal subjects and intensified the levels of asymmetry between members of the federation.

Also regional clientelism is already working against the creation of a new intermediate level of bureaucracy beholden to Putin. Each of the seven polpredy have begun to build up their staffs based on patron-client relations, much as the President himself has appointed to his administration many of his former associates from St Petersburg and the security services. As Badovskii notes in some regions the polpredy have acted as a powerful force limiting the powers of the regional governors. But, in many regions, the apparatus of the polpredy is created from the governor's people, is quickly integrated and absorbed by the local elites, and we see the merging or joining of federal and regional bureaucracies eventually creating a highly effective system of regional lobbying. ${ }^{21}$ The relations between governors, presidential representatives, and federal bureaucrats is still unclear and will undoubtedly vary from district to district. As Orttung and Reddaway note: 'Rather then creating a stronger vertical hierarchy of authority leading from the central government to the regions, Putin has created a triangle, with the ministries, the presidential representatives, and the regions making up the triangle's three points' ${ }^{22}$ It is also becoming apparent that such power relations will be worked out on the ground and cannot be planned and mapped out by Putin at the centre.

\section{Reform of the Federation Council}

In a second major initiative Putin stripped the governors and chairs of regional assemblies of their ex officio right to sit in the upper chamber of the parliament. ${ }^{23}$ These were to be replaced (from January 2002), with 'delegates' chosen by the regional assemblies and chief executives. More specifically, the governors have the right to appoint and dismiss their delegates as long as their choice of candidate is not vetoed by a vote of two-thirds of the members of their regional parliaments. And the regional assemblies appoint and dismiss their representatives according to their own voting procedures.

For a number of commentators, such changes will inevitably lead to a decline in the powers of the upper chamber and perhaps even in the long run to a situation whereby the upper house may be dispensed with altogether. As Kostyukov argues, the Federation Council will soon be filled with nonentities, 'bureaucrats beholden to their regions and without any political clout in Moscow's corridors of power'. ${ }^{24}$

On the other hand, as Putin himself has stressed, the new body will now meet full time, and not as in the past just for a few days a month. This will give the new members, who are totally reliant on their masters in the regions, far greater opportunities to scrutinise legislation coming 
from the Duma and presidency. And we will no longer have the spectacle of members of the executive sitting in a legislative chamber thus making a mockery of the principle of the separation of executive and legislative powers.

And, it is by no means the case, that the representatives of the governors and assemblies are as Kostyukov argues, 'non-entities'. Indeed, an examination of those selected shows this to be far from true. Indeed in a surely unforeseen scenario we have witnessed the selection of outgoing governors to represent incoming governors, ${ }^{25}$ or the choice of deputy governors as representatives. Legislative chairs have also selected high ranking members of their assemblies as their representatives. ${ }^{26}$ And in other cases, regions have chosen Moscow insiders or high ranking entrepreneurs. ${ }^{27}$ However, it must also be noted that these changes undermine King's stress on the 'legislative entrenchment' of the regions in central decision making (see chapter 1) as many of the new appointees to the upper chamber have only very tenuous links with their regions, or in some cases, none at all.

More worrying for the governors is the fact that when they are denied membership of the upper chamber they will automatically lose their right to immunity from criminal prosecution. And they will no longer have a direct say in the ratification of top posts to the judiciary and procuracy (although this will fall to their delegates). Putin will now be able to use the threat of prosecution to keep the chief executives in line.

\section{The State Council}

To sweeten the pill and to partially compensate the regional elite for their loss of membership in the upper chamber, Putin on September 1, 2000 created a new presidential advisory body - the State Council. ${ }^{28}$ The new body which is made up of all of the chief executives from the regions meets once every three months and is chaired by the President. There is also an inner presidium made up of seven governors (one from each of the federal districts), whose membership rotates each six months. The members of the presidium meet with the President once every month.

However, neither the State Council nor its presidium is likely to have real powers. The new body is purely consultative and has no law making functions. Moreover, as it was drawn up by presidential decree, it may similarly be dissolved by the President if it is not to his liking. The magazine Itogy has called the new council 'the factory of governor's dreams'. ${ }^{29}$ Its main aim at present is to give the regional leaders a direct channel to the President and some limited input into policy making. However, as Teague notes, there may be a more sinister motive behind the creation of the new Council. Putin may be planning in the future to replace the Federation Council with this much weaker rubber stamping body. ${ }^{30}$ 


\section{Dismissal of governors and dissolution of regional legislatures}

The third major reform strikes at the very heart of the regions' power structures - a new law giving Putin powers to dismiss popularly elected governors and to dissolve regional assemblies. ${ }^{31}$ As Putin explains such legislation now makes it possible for federal intervention 'in situations in which government bodies at the local level [have flouted] the Russian Constitution and federal laws, violating the uniform rights and freedoms of Russian citizens'.$^{32}$ The new law gives both chambers of the legislature, the general procurator and the regional legislatures the right to recommend that a governor be removed. However, as Corwin notes, the process is so long and involved that regional leaders would have to demonstrate 'unprecedented obstinacy, audacity, and even stupidity' before they could be fired. For a regional head to be dismissed: 'One, he must on two different occasions ignore presidential decrees, two, allow the passage of two bills with provisions that violate federal laws, or three, make use on two different occasions of regional acts previously denounced by the president or the courts. And, in each of these cases, a court verdict is required ruling that these actions constitute violations of federal law ${ }^{\prime 3} .^{33}$

The president can also temporarily remove a governor while criminal charges that have been filed against him are being studied. If the president removes a governor from office he appoints a temporary governor to replace him. However, it is interesting to note that Putin did not use his new powers against the Governor of Primorskii krai, Yevgenii Nazdratenko. Instead Putin simply dismissed Nazdratenko and to keep him quiet, rewarded him with a ministerial post in Moscow. Moreover, as Orttung and Reddaway note: 'even if the president does force a governor out of office, the region will hold new elections within six months, and there is no guarantee that the new governor will be any more pleasing to the federal government than the old one'. ${ }^{34}$

The law also calls for the dissolution of regional assemblies if they violate federal legislation. According to this legislation regional assemblies have three months to amend any legislation that violates federal laws or legal proceedings may be enacted against them. However, the president must gain the approval of the State Duma before an assembly can be dissolved. Whilst it is certainly the case that regional assemblies do pass legislation that infringes the constitution, it is highly questionable that Putin's right to dissolve democratically elected assemblies is itself constitutional.

\section{The governors' rights to dismiss lower level officials}

Putin also steered passage of a law through the Duma which gives the governors the right to dismiss lower level administrative heads (with the 
exception of the mayors of capital cities) within their regions. As Putin explained: 'if under certain conditions, the head of a region can be removed from office by the country's president, then the regional leader should have a similar right with respect to lower-ranking authorities' ${ }^{35}$

Also to win over the governors' support Putin promoted the so-called third-term law in the Duma. Under this law, the leaders of 69 Federation members will now be able to run for a third term and some even for a fourth even although such extensions to their tenure violate regional charters and republican constitutions (see chapter 9). ${ }^{36}$

\section{Bringing regional legislation into line with federal laws}

One of the main aims of the Putin's reforms is to create a unified legal space in the Russian Federation. To this end therefore, the polpredy have been charged with overseeing the complex process of bringing republic constitutions and regional charters (and other local laws and decrees) into line with the federal constitution and federal laws. By 2001 the number of normative legal acts adopted by the regions and republics exceeded 300,000 , and of these, just under a quarter $(70,000)$ contradicted the federal constitution and federal laws. ${ }^{37}$

Within a matter of just a few months after his election to the Russian Presidency in March 2000, Putin issued decrees demanding that the republics of Adygeya, Altai, Bashkortostan and Ingushetiya; and Amur, Smolensk and Tver oblasts, bring their regional laws into accordance with the Russian Constitution and federal legislation. Putin's decrees were backed up by two landmark decisions of the Constitutional Court (adopted on June 7 and June 27, 2000) which ruled that the republics' declarations of sovereignty were incompatible with the sovereignty of the Russian Federation. ${ }^{38}$

In its ruling of June 7 the court declared that several clauses in the Altai Constitution were illegal. In particular the court ruled against Altai's declarations of sovereignty, stating that 'the subjects of the Russian Federation do not possess any state sovereignty, which belongs to the Russian Federation alone'. And on June 27 the court declared that similar clauses in the constitutions of Adygeya, Ingushetiya, Bashkortostan, Komi, North Osetiya, and Tatarstan were also illegal. ${ }^{39}$

In August 2000 the Chief Procurator of the Russian Federation called for all regional laws to be brought into line with federal laws by January 1, 2001. And reporting back, in January 2001, the deputy head of the Presidential Administration, Dmitrii Kozak, boasted that about 80 per cent of the regional laws checked by the administration had either already been brought into compliance with federal law, or were being considered in the courts. ${ }^{40}$ In the same month Putin declared that sixty constitutions and regional charters, as well as over 2,000 regional laws had been brought 
into compliance with the constitution. ${ }^{41}$ However, there would appear to be as many different figures about the number of laws which have been brought into line as there are members of the presidential administration, and as Orttung notes there are good reasons to believe, 'that the numbers they cite are probably about as meaningful as Soviet era crop statistics'. In April 2001 the Justice Ministry reported that 23 regions continued to adopt laws which contradicted federal legislation. According to Interfax these regions included the republics of Adygeya, Altai, Ingushetiya, Bashkortostan, Komi, Tatarstan, Sakha and Tyva in addition to Arkhangelsk, Voronezh, Novgorod, Pskov, Ryazan, Moscow, Kamchatka, Irkutsk, Novosibirsk, Chita, Sverdlovsk and Chelyabinsk regions; Krasnoyarsk Krai, and the cities of Moscow and St Petersburg. ${ }^{42}$ And in his April 2001 address to the Russian Parliament, Putin declared that over 3,500 normative acts adopted in the regions contradicted the Russian Constitution and federal laws. ${ }^{43}$

Indeed, it is possible that the number of laws violating federal norms may actually have grown in number! As I demonstrate below we are still very far away from the creation of a 'unified legal space' in the Russian Federation.

Putin's efforts efforts to rein in the regions has elicited a range of reactions from reluctant acquiescence to outright defiance. Many republics and regions have dragged their feet in implementing the reforms and/or they have steadfastly refused to renounce their sovereignty and their control over natural resources. And just as quickly as old legislation is being revised to conform to federal norms, regional and republican parliaments have been able to adopt new laws with new infringements. For example, more than two dozen amendments made to the constitution of Khakasiya (in its revised edition of November 21, 2000) are in violation of federal laws. ${ }^{44}$ And only under considerable pressure from the presidential representative in the Siberian district and threats that federal subsidies would be cut off, did Tyva finally adopt a new version of its constitution on May 6, 2001. The previous version of the constitution gave the republic the right to secede from Russia and declared that only republican laws would be in effect during crises (see chapter 3). However, there have been so many legal violations in the process of writing the new constitution that its legitimacy is now being challenged in the courts. ${ }^{45}$

In Bashkortostan the new Constitution which was adopted in November 2000 is reported to contain almost as many violations as the old one! And whilst the new version, places limits on the republic's sovereignty, no longer declares its laws above Russian laws, removes claims that the republic is a subject of international law, and introduces procedures for appointing judges and procurators in line with federal norms, it still includes the full text of the Republic's power-sharing treaty. ${ }^{46}$ The Bashkortostan authorities have refused to recognise the rulings of the 
Russian Constitutional Court and continue to adopt legislation that violates federal laws. ${ }^{47}$ In December 2001, 72 per cent of Bashkortostan's laws still violated federal norms, a figure which was actually higher than it was in May 2000 at the beginning of Putin's reforms. ${ }^{48}$

The Tatarstan leadership has also steadfastly refused to renounce the Republic's sovereignty, and a Bilateral Commission set up to examine the Republic's Constitution also agreed to uphold the 1994 bilateral treaty, 'even though it contradicts both the federal and republican constitutions in several places'. Moreover, President Shaimiev has repeatedly called for the Russian Constitution to be brought into line with republican constitutions rather than vice versa. As Graney observes, Tatarstan's strategy of defiance includes, 'a legal defense of the republic's sovereignty... appeals to international bodies for help in protecting Tatarstan's sovereignty, political maneuvering aimed at forcing the centre to take a more moderate position on re-centralisation, attempts to co-opt various agents of federal re-centralisation' ${ }^{49}$ or simply ignoring federal laws and decrees.

It is also informative to note that the presidential representative in Tatatarstan, General Marsel Galimardanov, is not only an ethnic Tatar, but he is from the same rural district as President Shaimiev, which surely must lead us to question where his real loyalties lie - to his master in the Volga Federal District (Kirienko) or Tatarstan $?^{50}$

Likewise in Sakha there has been strong opposition to Putin's reforms. Thus, for example, on January 16, 2001 the Sakha Republican Legislature rejected a law proposed by the Republican Procurator that would have renounced the Republic's sovereignty. Nineteen of the legislature's thirtytwo members voted against it. And in March 2001, the legislators (in the lower house of the republican parliament) refused to make amendments to article 5 of the Republic's Constitution which gives it ownership over its land and natural resources. The Sakha government had signed a 25year agreement with the Alrosa diamond company on January 11, 2001, and it was in no mood to give up its control over such a lucrative source of income. Diamond production in the republic makes up 77 per cent of the government's revenue. ${ }^{51}$ However, the legislators did agree to remove from the Republic's constitution ten of the most egregious violations of federal law, including a provision which allowed the republic to have its own army ${ }^{52}$ However, little progress had been made in amending Sakha's constitution by the summer of 2001. Thus, for example, on May 3, 2001, the Sakha (Yakutiya) Supreme Court declared that about half of the 144 articles in the republican constitution were unconstitutional. ${ }^{53}$

And it is not only in the republics that such infringments of federal legislation have taken place. Thus, Latyshev, the presidential representative to the Urals Federal District, in an examination of 1,544 regional laws found that 306 violated the Russian constitution and federal legislation. The study also revealed that 92 per cent of municipal charters and 48 of 
the 67 agreements signed between federal agencies and regional executive branch agencies in the federal district also violated federal laws. ${ }^{54}$ Within the Urals Federal District, the governor of Sverdlovsk Oblast, Rossel, has been particularly defiant. An analysis of 157 regional laws in his region uncovered federal violations in eighty one. And by January 2001 the regional Duma had only amended 22 of these. ${ }^{55}$. The head of the Constitutional Court, Marat Baglai, who visited Sverdlovsk in January 2001, called for the region to speed up its programme for bringing its legislation into line. Baglai justified his demands by declaring that it 'was impermissible for citizens of Russia to have different rights in different regions'.

In the summer of 2001 Putin, realising that his reforms were being bogged down, announced a new initiative - the setting up of a commission to examine Russia's bilateral treaties. Addressing the first session of the commission, which took place on July 17, 2001, Putin admitted that adding yet another layer of bureaucracy to deal with the governors had been a failure. Regional leaders, he noted, had responded by building 'a Great Wall of China' between themselves and the centre. ${ }^{56}$ The commission called for regions to unilaterally rescind their bilateral treaties. However, to date only six regions have withdrawn from the powersharing agreements (Marii El Republic, and Perm, Nizhnii Novgorod, Ulyanovsk, Omsk and Novosibirsk oblasts). ${ }^{57}$ It remains to be seen how many others will follow.

\section{Putin's federal reforms and democracy}

There is a paradox at the heart of Putin's reforms - that is, they can be read as both promoting and restricting democracy. Bringing regional legislation into line with the Russian Constitution is absolutely essential for the consolidation of democracy, particularly in those ethnic republics which have deprived their citizens of universal democratic norms and human rights (see chapter 9). Thus for example recent moves to bring Bashkortostan's law enforcement bodies into line has undoubtedly improved the human rights of citizens in the Republic. In May 2001 under pressure from federal authorities Bashkortostan Prosecutor Yavdat Turumtaev admitted that republican law enforcement agencies 'grossly violated criminal procedure law' and that 50 per cent of all arrests and detentions in the republic were illegal. A total of 2,545 individuals have recently filed suits claiming that they were arrested and detained illegally. By reasserting the rule of law and due process, Putin's reforms in Bashkortostan and many other republics are positive steps in creating equal rights for all citizens across the federation. However, Putin's new powers to sack democratically elected governors and to dissolve regional legislatures is a setback for the consolidation of democracy.

Whilst most students of Russian federalism support Putin in his quest 
to discipline unruly regional bosses, many have argued that the President's radical reform of the federal system may have ended up, throwing the baby out with the bath water. Putin, it is argued, could have simply called for a more vigorous enforcement of existing executive powers.

There are real worries that Putin's quest for law and order will be bought at the expense of civil liberties and the consolidation of democracy. For Boris Berezovskii, Putin's reforms, 'will destroy the system of the balance of power, which is necessary for the normal functioning of any democratic government and market economy, significantly increase the authority of the executive branch of power at the expense of the legislative and limit citizens' participation in the representative management of government'. ${ }^{58}$

Moreover, Putin's reforms also put into doubt his adherence to the principles of federalism as enshrined in the Russian Constitution. In his book, First Person, Putin states that, 'from the very beginning, Russia was created as a super centralised state. That's practically laid down in its genetic code, its traditions, and the mentality of its people ${ }^{\prime 59}$ Putin's reorganisation of the Federation Council, his usurpation of unilateral powers to dismiss regional assemblies and chief executives, combined with his creation of the seven federal districts, make a mockery of federalism and democracy. 'What kind of federation is it', asked President Ruslan Aushev of Ingushetiya, 'if the president can remove the popularly elected head of a region or disband the regional legislature' ${ }^{60}$ Moreover, as Chuvash President, Nikolai Fedorov, has pointed out, the people have no way to democratically check the activities of the seven unelected presidential representatives. ${ }^{61}$

As we noted in chapter 1, in federations, regional autonomy is constitutionally guaranteed. The 'noncentralisation' of federations must be distinguished from the 'decentralisation' of unitary states. In other words, in federations there is a vertical separation of powers among federal and regional bodies of power, each of which have constitutionally guaranteed rights and powers. As Smirnyagin notes, in a federation, each tier of government is 'chosen at separate elections by the state's citizens, who give each its own legitimacy and make it independent of the others' ${ }^{62}$ Putin cannot legally centralise policy areas which have been constitutionally assigned to the regions or which come under the joint authority of the regions and the federal government. The federal government cannot simply ignore the rights of the federal subjects without itself violating the Constitution and undermining both federalism and democracy. Moreover, Putin's claim that his reforms are wholly within the ambit of the Constitution is patently absurd. His attempts to justify his reforms by stating that they are reforms of his presidential administration and not of the country, remind us of Yeltsin's cynical manipulation of the Constitution and his penchant for ignoring federal laws whenever it suited him (see 
chapter 9). Putin would appear to be following in the footsteps of a long line of previous Soviet leaders, who seek to justify the 'means' by reference to the 'ends'.

Finally, Putin faces the same dilemma as that of Gorbachev and Yeltsin before him, how to maintain the unity of the state without abandoning a commitment to democratisation. At present it would appear that Putin is willing to sacrifice democracy in order to win unity. However, his attacks on the sovereignty claims of the republics are surely just as likely to stirup nationalist sentiments as to quell them. Putin will have to tread carefully if he does not want to lead Russia back to the chaotic days of the 'parade of sovereignties'.

\section{Notes}

1 See, Presidential Decree no. 765, July 23, 1992, ‘Ob utverzhdenii polozheniya o predstavitele Prezidenta Rossiiskoi Federatsii v krae, oblasti, avtonomnoi oblasti, avtomnon okruge, goradakh Moskve i Sankt-Peterburge', Vedemostii S'ezda Deputatov Rossiiskoi Federatsii i Verkhovnovo Soveta Rossiiskoi Federatsii, 29 (July 23, 1992), 2163; Presidential Decree no. 186, February 5, 1993, 'O predstavitele Prezidenta Rossiiskoi Federatsii v krae, oblasti, avtonomnoi oblasti, avtomnon okruge, goradakh Moskve i Sankt-Peterburge'; Presidential Decree of January 17, 1995, 'O vnesenii izmenenii i dopolnenii v Ukaz Prezidenta Rossiiskoi Federtatsii ot 5 Febralya 1993 no. 186, ‘O predstavitele Prezidenta Rossiiskoi Federatsii v krae, oblasti, avtonomnoi oblasti, avtomnon okruge, goradakh Moskve i Sankt-Peterburge'; Presidential Decree no. 696, July 9, 1997, 'O polnomochnom predstavitele Prezidenta Rossiiskoi Federtatsii v regione Rossiiskoi Federatsii', Sobranie Zakonodatel'stva Rossiiskoi Federatsii, 28 (1997), 3421. See also the accompanying statute to the 1992 Decree, 'O predstavitele Prezidenta Rossiiskoi Federatsii v krae, oblasti, avtonomnoi oblasti, avtomnon okruge, goradakh Moskve i Sankt-Peterburge', Rossiiskaya gazeta (July 24, 1992).

2 P. Kirkow, Russia's Provinces: Authoritarian Transformation versus Local Autonomy? (Basingstoke: Macmillan, 1998), p. 123.

$3 \mathrm{M}$. Hyde, 'Putin's federal reforms and their implications for presidential power in Russia', Europe-Asia Studies, 53:5 (2001), 722. See also, W. A. Clark, 'Presidential prefects in the Russian provinces: Yeltsin's regional cadres policy', in Graeme Gill (ed.), Elites and Leadership in Russian Politics (New York: St Martin's Press, 1998), and I. Busygina, 'The President's representatives: problems of establishing and developing an institution', Russian Politics and Law, 35:1 (1997).

4 J. Helmer, 'Russia: regions pressure Kremlin into policy shift - an analysis', Radio Free Europe/Radio Liberty, Daily Report (November 4, 1997), 2.

5 V. V. Putin, 'Television address by the Russian President to the Country's citizens', Rossiiskaya gazeta (May 19, 2000), p. 3. Translated in CDPSP, 52:20 (2000), 5 .

6 Ibid. 
7 M. Evangelista, 'Russia's path to a new regional policy', Davis Centre for Russian Studies, Harvard University, PONARS Policy Paper, 157 (2000), p. 3.

8 Thus for example, Vladimir Gustov was appointed First Deputy Prime Minister in charge of regional issues. Primakov also established a new Ministry of Regional Policy headed by Viktor Kirpichnikov, the leader of the Union of Russian Cities.

9 N. Petrov, 'Russia's regions or regions' Russia?', Carnegie Briefing Papers, 3 (March 1999), 4.

10 See, Presidential Decree, no. 849, May 13, 2000, ‘O Polnomochnom Predstavitele Prezidenta Rossiiskoi Federatsii v Federal'nom Okruge', and the accompanying Resolution, ‘O Polnomochnom Prestavitele Prezidenta Rossiiskoi Federatsii v Federal'nom Okruge'. Published in Rossiskaya gazeta (13 May, 2001).

11 J. A. Corwin, RFE/RL Russian Federation Report, 2:9 (March 7, 2001), 5.

12 O. Oracheva, 'Democracy and federalism in post-communist Russia (relations between Moscow and the regions in the Russian Federation)', paper presented at the conference, 'The Fall of Communism in Europe: Ten Years On', May 14-17, 2001, The Hebrew University of Jerusalem, p. 11.

13 'Presidential administration's Samoilov on seven representatives', EWI Russian Regional Report, 5:30 (August 2, 2000), 4-6.

14 See, E. Teague, 'Putin reforms the federal system', and R. Sakwa, 'Federalism, sovereignty and democracy', in C. Ross (ed.), Regional Politics in Russia (Manchester: Manchester University Press, 2002), M. Hyde, 'Putin's federal reforms and their implications for presidential power in Russia', Europe-Asia Studies, 53:5 (2001), 719-43. The duties of the 'polpredy' were further outlined in Putin's Presidential Decree of January 30, 2001, no. 97, 'O Vnesenii dopolneniya I izmeneniya v polozhenie o polnomochnom predstavitele Prezidenta Rossiiskoi Federatsii v federal'nom okruge, utverzhdennoe ukazom Prezidenta Rossiiskoi Federatsii ot 13 Maya 2000 No 849'. Published in Rossiskaya gazeta (30 January 2001). According to this decree the presidential envoys were directly subordinate to the head of the Presidential Administration.

15 Speech by V.V. Putin at the Presentation of the Annual Message from the President of the Russian Federation to the Federal Assembly of the Russian Federation, Rossiiskaya gazeta (July 11, 2000), pp. 1, 3. Translated in CDPSP, 52(28) (2000), p. 7.

16 Interview with S. Kirienko, Nezavisimaya gazeta (October 25, 2000), p. 3.

17 D. V. Badovskii - 'Systema federal'nykh okrygov i institut polnomochnykh predstavitelei prezidenta RF: sovremennoe sostoyanie i problemy razvitiya', in Polpredy Prezidenta: Problemy Stanovleniya Novovo Instituta (MGU, Nauchnye Doklady, no. 3, January 2001), p. 5.

18 A. Slabov, 'Georgy Poltavchenko raises his voice', Kommersant (February 10, 2001), 2. CDPSP, 53:6 (March 7, 2001).

19 It is also interesting to note that the political movement 'Otechestvo' has begun to restructure its party-territorial structures in conformity with the new federal districts.

20 I. Gordeyev, Vremya Novostei (January 12, 2001), 1.

21 Badovskii, 'Sistema federali'nykh okrugov', p. 6.

22 R. Orttung and P. Reddaway, 'Russian state-building: the regional dimension', in The Russia Initiative: Reports of the Four Task Forces (New York: Carnegie Corporation, 2001), p. 100. 
23 See, the Federal Law, no. 113-F3, August 5, 2000, 'O Poryadke Formorovaniya Soveta Federatsiya Federal'novo Sobraniya Rossiiskoi Federatsii'. Adopted by the state Duma July 19, 2000 and ratified by the Federation Council July 26, 2000, Rossiskaya gazeta (August 5, 2000).

24 A. Kostyukov, Obshchaya gazeta, 30 (July 27-August 2, 2000), pp. 1-7. Translated in the CDPSP, 52:30 (2000), 5.

25 The Governor of Kaluga, Vyacheslav Parinov appointed his predecessor Valerii Sudarenko; Chukotka Governor Roman Abramovich appointed his predecessor Aleksandr Nazarov. In Altai krai, Governor Aleksandr Surikov named Vladimir Germanenko, a deputy governor in the krai; Andrei Chirkin, the First Deputy Governor of Khabarovsk Krai, will represent the krai administration. And Viktor Stepanov, former head of Kareliya was selected to represent that Republic's presidential administration. J. A. Corwin, RFE/RL Federation Report (December 16, 2001) as cited in Kommersant-Daily (December 15, 2001).

26 The legislature in Buryatia selected Vladimir Bavlov, Deputy Chair of Buryatia's Committee on Natural Resources; legislators in Amur Oblast selected Galina Buslova, General Director of the Aviation Agency 'Aviatrast'; Deputies in Khabarovsk Krai's Legislature confirmed the selection of the former chair of the krai legislature, Viktor Ozerov as their representative. J. A. Corwin, RFE/RL Russian Federation Report (December 16, 2001), 2.

27 The head of 'Transaero', Aleksandr Pleshakov was nominated by the Governor of Penza oblast; Sergei Bekov, Vice President of the Russian Union of Industrialists and Entrepreneurs (Ingushetiya); Leonid Binder, a Norislk Nickel Executive (Taimyr AO); Ilya Lomakin-Rumyantsev, a former Federal Finance Ministry official (Marii-El). Oleg Deripasta, the Head of 'Siberian Aluminium' (Nizhnii Novgorod). J. A. Corwin, RFE/RL Russian Federation Report, 3:12 (April 4, 2001), 2.

28 'Ukaz Prezidenta Rossiiskoi Federatsii', no. 602, September 1, 2000, published in Rossiiskaya Gazeta (September 1, 2000).

29 I. Busygina 'Federalism and the administrative reforms of President Putin in the context of the democratic transition in Russia', unpublished have presented at the winter 2000 SRC symposium, p. 8.

30 Putin here would appear to be borrowing ideas from Russia's past. The State Council was the supreme consultative body in the Russian Empire from 1810 to 1917. And a State Council also functioned in the Soviet Union for just a few months after the failed August 1991 Coup.

31 The law on the removal of the governors and disbanding of legislatures takes the form of amendments to the Federal Law 'Ob Obshchikh Printsipakh Organizatsii Zakonodatel'nykh (Predstavitel'nykh) i Ispolnitel'nykh Organov Gosudarstvennoi Vlasti Sub'ektov Rossiiskoi Federatstii', which was ratified by the President on October 6, 1999. Published in Rossiskaya gazeta (October 19, 1999).

32 'Annual message of the President to the Russian Federal Assembly', Rossiiskaya gazeta (July 11, 2000), 3. Translated in CDPSP 52:28 (2000), 7.

33 J. A. Corwin, 'Vulnerability of governors to dismissal questioned', RFE/RL Russian Federation Report, 2:21 (June 7, 2000).

34 Orttung and Reddaway, 'Russian state building', p. 98.

35 Putin, 'Television address', 5.

36 A. Kostyukov, Obshchaya gazeta, 5 (February 1-7, 2001), p. 1. This amends a 
previous law adopted in October 1999 which limited governors to two terms. The amendment counts the first term for a governor as the one starting after October 16, 1999.

37 M. I. Vil'chek, 'O klyuchevikh problemakh stanovleniya instituta polnomochnykh predstavitelei Prezidenta RF', in Polpredy Prezidenta, p. 20.

38 Resolutions of the Constitutional Court of June 7, and June 27, 2000 repudiated the sovereignty of the republics as not in line with the Federal Constitution. See, M. V. Baglai, Konstitutsionnoe Pravo Rossiiskoi Federatsii (Moscow: Norma, 2001), pp. 305, 338-9. This same resolution also noted that it was against the Constitution for regional organs of power to appoint officials of federal bureaucracies in the regions.

39 K. E. Graney, 'Ten years of sovereignty in Tatarstan: end of the beginning or beginning of the end?', Problems of Post-communism (September/October 2001), 37.

40 J. A. Corwin, RFE/RL Russian Federation Report, 3:2 (January 10, 2001) as cited in Obshchaya gazeta, 52 (January 10, 2001).

41 Interfax (January 11, 2001).

42 J. Corwin, RFE/RL Russian Federation Report, $3: 13$ (April 11, 2001), 1.

43 R. Orttung, EWI Russian Regional Report, 6:18 (May 16, 2001), 2.

44 M. Shandarov, EWI Russian Regional Report, 6:5 (February 7, 2001), 5.

45 Kommersant Daily (May 8, 2001).

46 I. Rabinovich, 'Bashkortostani legal situation is worse than before campaign to bring laws into line', EWI, Russian Regional Report, 6:44 (December 12, 2001), 10.

47 Ibid., 11.

48 Ibid., 10.

49 Graney, 'Ten years of sovereignty', 37-8.

$50 \mathrm{Ibid} ., 38$.

51 O. Yemelyanov, EWI Russian Regional Report 6:3 (January 24, 2001), 3.

52 EWI Russian Regional Report, 6:10 (March 14, 2001), 6.

53 R. Orttung, EWI Russian Reional Report, 6:18 (May 16, 2001), 4.

54 S. Pushkarev, EWI Russian Regional Report, 6:9 (March, 7, 2001), 4-5.

55 EWI Russian Regional Report, 5:47 (December 20, 2000), 5.

56 J. A. Corwin, RFE/RL Russian Federation Report, $3: 21$ (July 18, 2001), 2.

57 Ibid., 3.

58 B. Berezovskii, 'Open letter to President Putin', Transitions (June 5, 2000), p. 1.

59 V. Putin, First Person: An Astonishingly Frank Self-Portrait by Russia's President Vladimir Putin, with N. Gevorkyan, N. Timakova and A. Kolesnikov; translated by C. A. Fitzpatrick (London: Hutchinson, 2000), pp. 182-3. Cited in R. Sakwa, 'federalism, sovereignty and democracy', in C. Ross (ed.), Regional Politics in Russia (Manchester: Manchester University Press, 2002), p. 18.

60 Graney, 'Ten years of sovereignty', 37.

61 N. Fedorov, Nezavisimaya gazeta (October 25, 2000), 2.

62 L. V. Smirnyagin, 'Federalizm po Putiny ili Putin po federalizmu (zheleznoi pyatoi)', Carnegie Briefing Papers, 3:3 (March 2001), 3. 